\title{
Differential Defense Reactions in Leaf Tissues of Barley in Response to Infection by Rhynchosporium secalis and to Treatment with a Fungal Avirulence Gene Product
}

\author{
Sabine Steiner-Lange, ${ }^{1}$ Achim Fischer, ${ }^{1}$ Annette Boettcher, ${ }^{2}$ Ila Rouhara, ${ }^{1}$ Hiltrud Liedgens, ${ }^{1}$ Elmon \\ Schmelzer, ${ }^{1}$ and Wolfgang Knogge ${ }^{2}$ \\ ${ }^{1}$ Department of Biochemistry, Max-Planck Institute for Plant Breeding Research, Carl-von-Linné-Weg 10, D-50829 Köln, \\ Germany; ${ }^{2}$ School of Agriculture and Wine, The University of Adelaide, Glen Osmond, SA 5064, Australia
}

Submitted 27 January 2003. Accepted 12 June 2003.

\begin{abstract}
Expression of defense-associated genes was analyzed in leaf tissues of near-isogenic resistant and susceptible barley cultivars upon infection by Rhynchosporium secalis. The genes encoding pathogenesis-related (PR) proteins PR-1, PR-5, and PR-9 are specifically expressed in the mesophyll of resistant plants, whereas a germin-like protein (OxOLP) is synthesized in the epidermis irrespective of the resistance genotype. Restriction-mediated differential display was employed to identify additional epidermis-specific genes. This resulted in the detection of another $P R$ gene, $P R-10$, along with a lipoxygenase gene, $\operatorname{Lox} A$, and a gene of unknown function, pI2-4, which are specifically induced in the epidermis of resistant plants. The gene encoding a putative protease inhibitor, $S D 10$, is preferentially but not exclusively expressed in the epidermis. The fungal avirulence gene product NIP1 triggers the induction of the four $P R$ genes only. At least two additional elicitors, therefore, must be postulated, one for the unspecific induction of $O x O L P$ and one for the resistance-specific induction of $\operatorname{LoxA}, p I 2-4$, and SD10. PR-10 expression can be assumed to be the consequence of NIP1 perception by epidermis cells. In contrast, gene expression in the mesophyll is likely to be triggered by an as yet unknown signal that appears to originate in the epidermis and that is strongly amplified in the mesophyll.
\end{abstract}

The leaves of grasses are the target organs for several microbial pathogens. Leaves are built of three major types of tissue: epidermis, mesophyll, and vascular bundles. The epidermis, which frequently consists of only a single cell layer, provides the first barrier to various environmental impacts. In many plants, it is the major accumulation site for secondary phenolics such as the flavonoids, suggesting a role in UV protection (Bieza and Lois 2001). Hydroxycinnamic acids are covalently bound in the thickened outer and anticlinal walls of epidermal cells (Carpita and Gibeaut 1993; Knogge and Weissenböck

S. Steiner-Lange and A. Fischer contributed equally to the work.

Corresponding author: W. Knogge; Telephone: +61-8-8303 6822; Fax: +61-8-8303 7109; E-mail: wolfgang.knogge@ adelaide.edu.au.

Current address for Achim Fischer: BASF-LYNX Bioscience AG, Im Neuenheimer Feld 515, D-69120 Heidelberg, Germany.

Nucleotide sequence data reported are available in the GenBank database under the following accession numbers: pI2-1, AY220734; pI2-2, AY220735; pI2-4, AY220736; pI8-6, AY220737; and pI8-16, AY220738.
1986), which, upon cross-linking, are expected to contribute to protection against attacking pathogens (Facchini et al. 2002; Iiyama et al. 1994). In contrast, the role of the recently described leucine-derived cyanoglucosides in barley epidermal cells in protection against pathogens remains elusive (Nielsen et al. 2002). Nevertheless, the exposed position of the epidermal cell layer prompts the question as to whether its role in disease resistance is restricted to providing passive protection against penetrating pathogens. Alternatively, epidermal cells may have a specific function in the plant's alert and active defense system.

In barley, the differential synthesis of defense-related proteins was demonstrated in leaf epidermis and mesophyll in response to attack by the powdery mildew fungus, Blumeria graminis f. sp. hordei (Christensen et al. 2002; Gregersen et al. 1997). No significant differences in gene expression patterns were observed during early stages of compatible and incompatible interactions of plants possessing the resistance genes $M l-a 1$ or $M l-a 3$ with B. graminis. However, pronounced differences were found in the tissue specificity of gene expression. Most analyzed genes were induced preferentially in the mesophyll. An exception was the gene encoding a germin-like protein (oxalate oxidase-like protein, OxOLP), transcripts of which were exclusively found in the epidermis. In contrast, another member of this protein family, oxalate oxidase $(\mathrm{OxO})$, was only synthesized in the mesophyll (Zhou et al. 1998). Despite the lack of resistance specificity, these results demonstrate a specific function of the epidermis in the plant defense response.

The biotrophic fungus $B$. graminis grows mainly ectophytically on the leaf surface extracting nutrients from the host by forming haustoria in epidermal cells. In contrast, the necrotrophic fungus Rhynchosporium secalis penetrates the leaf surface and grows extracellularly beneath the leaf cuticle throughout most of its life cycle (Lehnackers and Knogge 1990) (Fig. 1). While a hypersensitive response of the host plant is included in the $M l$ - $a$-mediated resistance to $B$. graminis, this reaction does not occur in incompatible interactions with $R$. secalis. When near-isogenic barley cultivars differing in the resistance gene Rrs 1 were inoculated with a fungal isolate expressing the complementary avirulence gene AvrRrsl, only the resistant plants showed a rapid, transient accumulation of mRNAs encoding pathogenesis-related (PR) proteins PR-5 (acidic form) and PR9 (peroxidase) (Hahn et al. 1993). When the same barley cultivars were treated with NIP1, the product of the avirulence gene AvrRrsl (Rohe et al. 1995), mRNA accumulation was restricted to the Rrsl cultivar (Hahn et al. 1993). 
An analysis of the tissue-specific expression of defense-associated genes by mRNA filter hybridization after tissue separation is expected to shed light on the contribution of the different tissues to the overall defense response of barley leaves to $R$. secalis infection. Furthermore, mRNA hybridization in situ allows an assessment of spatial gene expression and mRNA accumulation in relation to fungal development. Of particular interest is the question as to whether resistance is determined in the epidermis or in the mesophyll. Prerequisite, however, is the availability of appropriate probes. Therefore, a cDNA differential display technique (restriction-mediated differential display [RMDD]) was used to identify defense-related transcripts that are specifically induced in epidermal cells of resistant plants.

\section{RESULTS}

Tissue-specific expression of defense-related genes was analyzed in barley leaves inoculated with race UK7 of $R$. secalis (AvrRrs1) (Rohe et al. 1995). When RNA was isolated from separated epidermal and mesophyll tissues of cultivar Atlas 46 (Rrs 1$)$, cDNA probes corresponding to the genes encoding PR1b, acidic PR-5, and PR-9 detected mRNA accumulation exclusively in the mesophyll (Fig. 2; PR-1b not shown), whereas OxOLP mRNA was restricted to the epidermis. In contrast to the PR protein mRNAs (Hahn et al. 1993), OxOLP mRNA accumulated also in the susceptible near-isogenic cultivar Atlas (rrsl) (Fig. 2).

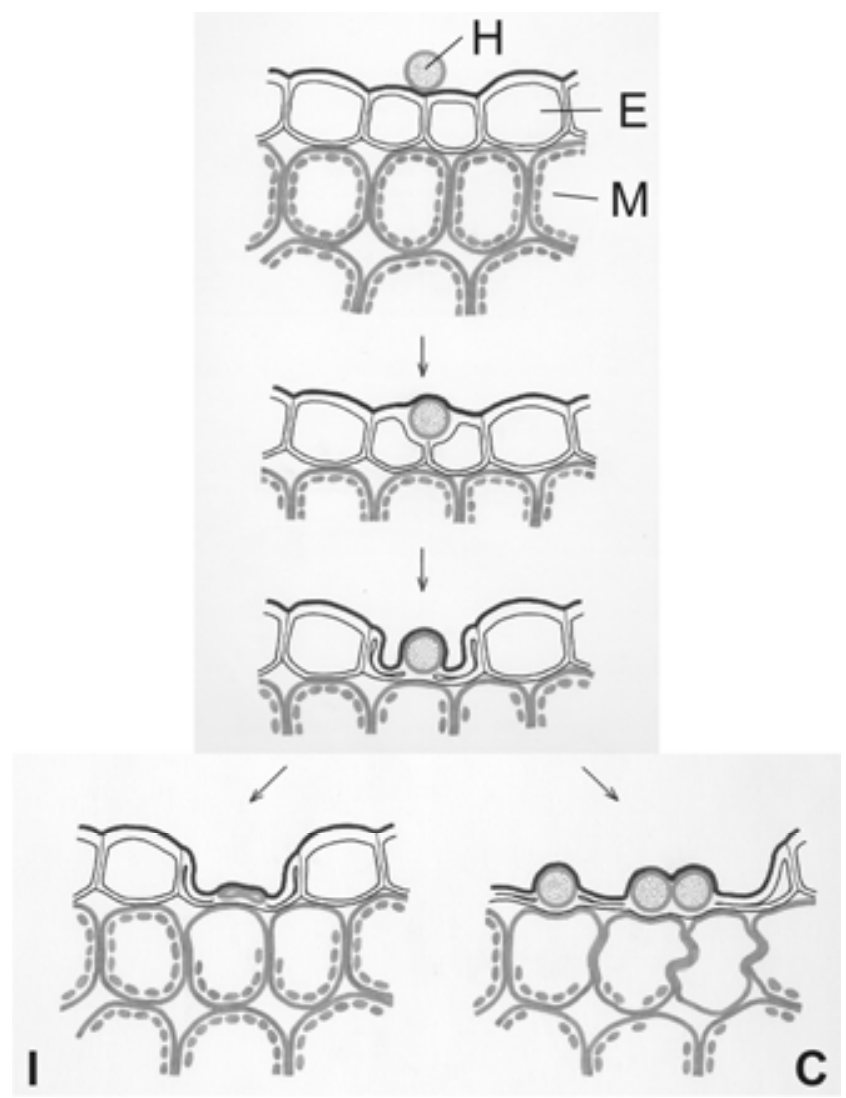

Fig. 1. Schematic depiction of the early stages in the development of Rhynchosporium secalis on barley leaves. Fungal hyphae $(\mathrm{H})$ have penetrated the leaf cuticle $24 \mathrm{~h}$ postinoculation (p.i.). Epidermal cells (E) in the vicinity of fungal collapse 3 to 4 days p.i. Through unknown mechanisms, fungal growth is arrested on resistant plants (incompatible interaction [I]), whereas epidermal collapse continues on susceptible plants (compatible interaction [C]). When the underlying mesophyll cells (M) collapse 2 weeks p.i., necrotic spots become visible. For clarity reasons dimensions of the fungal structures are shown oversized.

\section{Isolation of genes induced in the leaf epidermis upon fungal infection.}

To study the function of the epidermis in the defense response, a search was performed for additional defense-related genes that are specifically expressed in this tissue upon fungal infection. To this end, a RMDD strategy was used. Two poly $(\mathrm{A})^{+}$-RNA populations were prepared from epidermal tissue of resistant Atlas 46 leaves, either inoculated with the avirulent $R$. secalis isolate UK7 or control-treated. From both populations, cDNAs were synthesized, were cleaved with Sau3A, and were ligated with a linker. Fragments representing cDNA $3^{\prime}$ ends were amplified by polymerase chain reaction (PCR) using primers directed to the poly(A) tail and to the linker, respectively, thereby avoiding the use of arbitrary primers. To reduce the complexity of the mixture of PCR products, the linker-specific and the poly(A)-specific primers carry extensions of one nucleotide in the first round of amplification and of a further nucleotide in the second PCR, thus allowing the amplification of only a subset of the 3 ' ends of all cDNAs present in each reaction. In order to enable the amplification of the $3^{\prime}$ ends of all cDNAs within a mixture therefore, 192 different amplification reactions need to be performed. Since the linker-specific primers used in the second PCR were 5' biotinylated, amplification products could be visualized by serological staining after separation on a sequencing gel and blotting to a membrane, using the Direct Sequencing and Blotting System. Using 94 primer combinations, 12 bands (I1 to I12), appearing only in the PCR reactions using RNA from infected
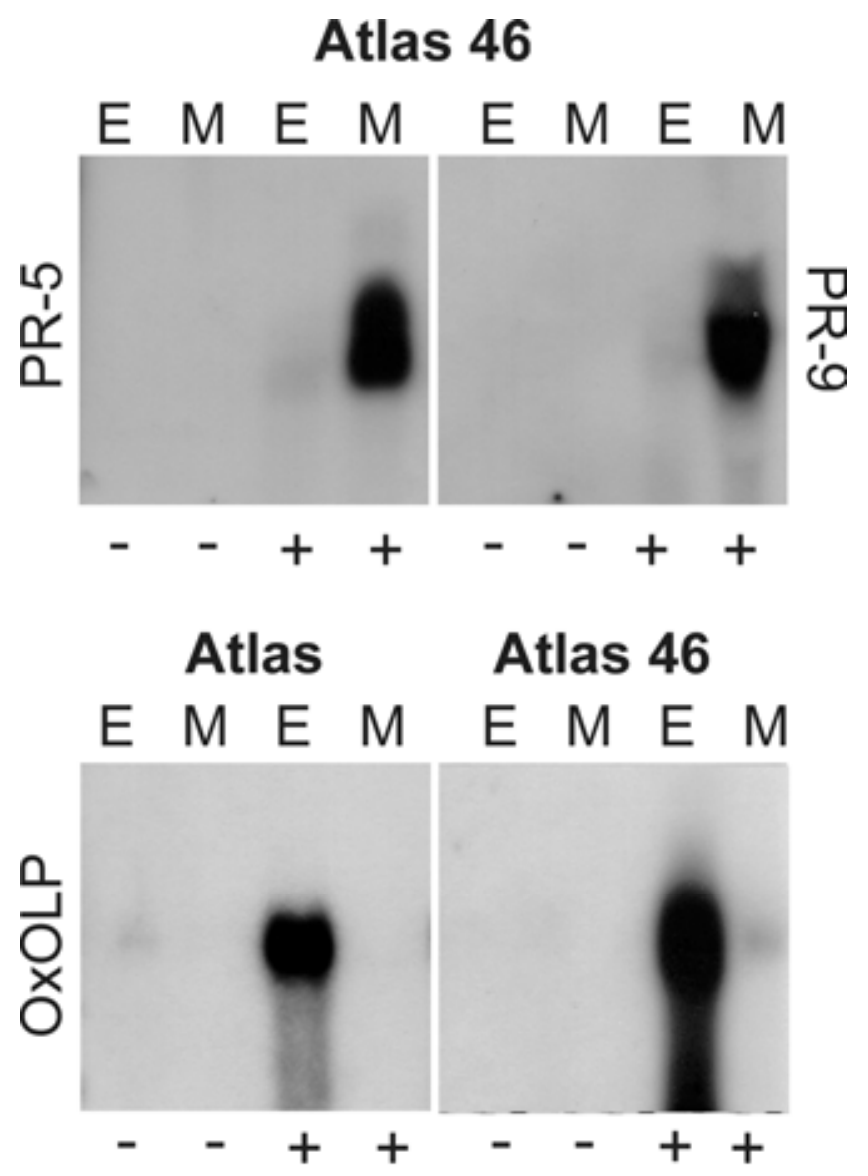

Fig. 2. Filter hybridization using epidermal (E) and mesophyll (M) RNA from cultivar Atlas 46 control-treated (-) or inoculated with race UK7 of Rhynchosporium secalis $(+)$ and probed with PR-5 and PR-9 cDNA (upper panels). Filter hybridization using epidermal and mesophyll RNA from susceptible cultivar Atlas and resistant cultivar Atlas 46 and probed with OxOLP cDNA (lower panels). 
leaves, were cut out from the membrane, were reamplified, and were subjected to direct sequencing.

\section{Analysis of candidate genes.}

Sequence analysis of the amplification products I1 to I12 revealed that two of them represent known barley genes. I1 corresponds to the gene encoding barley lipid transfer protein 2 (LTP2) (Molina and Garcia-Olmedo 1993), and I8 to the gene coding for barley lipoxygenase LOX-1 (LoxA) (van Mechelen et al. 1995). Furthermore, sequence analysis showed that two fragments had been isolated twice with two different primer combinations (I3/I6 and I5/I7) and one even three times with three different primer combinations (I4/I9/I11). Thus, the number of candidate genes was reduced to 8 (Table 1).

When the reamplified PCR products were used as probes in filter hybridizations with total RNA isolated from epidermal and mesophyll tissues of inoculated and noninoculated leaves, six of the eight fragments hybridized with epidermal RNA. Importantly, five showed a stronger or exclusive signal with RNA from infected leaves (I2, I3, I4, I5, and I8). I1 (LTP2) produced signals of equal strength with RNA from inoculated and noninoculated leaves, as did fragment I12 corresponding to a gene that is also expressed in the mesophyll. Fragment I10 failed to give a signal.

Since the differential screening for pathogen-induced genes was based on a comparison of mRNA populations from infected and noninfected leaves, signals exclusively appearing with RNA derived from infected leaves may represent fungal genes. Therefore, Southern- and Northern-type analyses were performed and revealed that I3, I4, and I5 are not of plant origin. I4 and I5 represent abundant RNAs that are present in $R$. secalis isolate UK7 but absent from 11 other isolates investigated, irrespective of the presence or absence of the NIPl gene (data not shown)

\section{Isolation and characterization of cDNA clones.}

The remaining amplification products $\mathrm{I} 2$ and I8 were used to isolate clones from a cDNA library synthesized from UK7infected Atlas 46 leaves. Sequencing of several clones revealed that, with both probes, three different cDNA species (pI2-1, pI2-2, and pI2-4; pI8-6, pI8-7, and pI8-16) had been isolated. This was likely due to the presence in the cDNAs of sequence stretches with $>50 \%$ identity with the I 2 and I8 sequences, respectively. The relatively low stringency that was used during the washing steps because of the small probe length (I2, $91 \mathrm{nt}$; I8, $217 \mathrm{nt}$ ), therefore, may have caused the isolation of the false positive clones. pI2-1, whose $3^{\prime}$ end corresponds to the I2 sequence, contains an open reading frame (ORF) of $498 \mathrm{bp}$. The deduced sequence of 166 amino acids shows homology (63\% similarity, $50 \%$ identity) to rice PR-10a, which is induced upon infection with Magnaporthe grisea (J. D. McGee, and T. K. Hodges, unpublished data) (accession number AF274850) and which is almost identical with a probenazoleinduced protein PBZ1 from rice (Midoh and Iwata 1996) and a PR-10 protein induced in sorghum upon infection with Cochliobolus heterostrophus (Lo and Nicholson 1998; Lo et al. 1999). In addition, the ORF is identical with an expressed sequence tag (EST) sequence (BE558328) from barley seedlings challenged with $B$. graminis. pI2-2 has an ORF of 444 bp encoding a protein with $95 \%$ identity to a ubiquitin-conjugating enzyme from maize (AF034946). Furthermore, 95 and $92 \%$ similarity, respectively, were found with ESTs representing mRNAs from Zea mays inoculated with Fusarium graminearum (BG837825) and Sorghum bicolor challenged with Colletotricum graminicola (BE599149).

pI2-4 contains an ORF of $540 \mathrm{bp}$ and shows homologies of 97\% to a cDNA (BM816768) from drought-stressed barley and $87 \%$ to an EST representing a maize mRNA (AY106903) and exhibits homology to ESTs representing partial cDNAs isolated from rice callus (C93431, 84.1\% identity in $347 \mathrm{nt}$ ) and from cotton ball abscission zones (AI055160, 71.8\% identity in $301 \mathrm{nt}$ ). The gene product shows $80 \%$ similarity, $65 \%$ identity, and $78 \%$ similarity, $63 \%$ identity, respectively, to the sequences of two auxin-regulated proteins from Arabidopsis thaliana (At2g21620, NP565515). Weaker homology (47\% similarity, $29 \%$ identity) was found with the nodulin VfENOD18 from Vicia faba (AJ271016.1) (Hohnjec et al. 2000), for which a function as ATP-binding protein or ATPase has been discussed, based on sequence homology to the ATPbinding protein MJ0577 from Methanococcus jannaschii.

Using fragment I8 as a probe, two different partial lipoxygenase cDNAs, pI8-16 and pI8-7, were isolated. pI8-16 corresponds with barley LoxA, which encodes a lipoxygenase of the LOX-1 type (van Mechelen et al. 1995). After a short unknown sequence of $56 \mathrm{bp}$, the clone comprises the LoxA ORF from position 2 of Trp codon 512 to the final codon 862 , followed by 235 bp of 3' untranslated sequence. In contrast, pI8-7 encodes a barley methyl jasmonate-induced lipoxygenase of the LOX-2 type (LOX2:Hv:1) (Vörös et al. 1998). The sequence starts at position 3 of His codon 311 and was probably isolated due to its similarity with LoxA. The final cDNA clone, pI8-6, has an ORF of $204 \mathrm{bp}$ that is identical with the ORF of SD10, a gene highly expressed in barley leaves during dark-induced senescence (Kleber-Janke and Krupinska 1997). The deduced protein has highest homology to protease inhibitors MPI from maize (64\% similarity, $49 \%$ identity) (Cordero et al. 1994) and CI-2A from barley (52\% similarity, 34\% identity) (Williamson et al. 1987).

\section{Gene expression upon fungal infection.}

The six cDNA clones were used as probes in filter hybridization experiments performed with total RNA from inoculated

Table 1. Candidate genes obtained by restriction-mediated differential display

\begin{tabular}{|c|c|c|c|c|c|}
\hline PCR product & Epidermal mRNA & cDNA clone & Origin & Gene activation & Sequence similarity of gene product \\
\hline I1 & + & & & - & LTP2 \\
\hline \multirow[t]{3}{*}{$\mathrm{I} 2$} & + & pI2-1 & Plant & + & PR-10 \\
\hline & & pI2-2 & Plant & - & Ubiquitin-conjugating enzyme \\
\hline & & pI2-4 & Plant & + & Drought-stress protein from barley \\
\hline I3/I6 & + & pI3 & Fungus & + & Cytochrome $\mathrm{C}$ \\
\hline I4/I9/I1 1 & + & pI4 & Fungus & + & \\
\hline I5/I7 & + & pI5 & Fungus & + & \\
\hline \multirow[t]{3}{*}{ I8 } & + & pI8-6 & Plant & + & SD10, putative proteinase inhibitor \\
\hline & & pI8-7 & Plant & - & Methyl jasmonate-inducible LOX-2 type (LOX2:Hv:1) \\
\hline & & pI8-16 & Plant & + & Lox-1 type $($ LoxA $)$ \\
\hline $\mathrm{I}-10$ & $\mathrm{nd}^{\mathrm{a}}$ & & & nd & \\
\hline $\mathrm{I}-12$ & - & & & - & \\
\hline
\end{tabular}

\footnotetext{
${ }^{\mathrm{a}}$ nd $=$ not detected.
} 
and noninoculated leaves of barley cultivar Atlas 46. The genes encoding PR-10, LOX-1, SD10, and the unknown protein pI24 were activated in inoculated leaves, with PR-10, LOX-1, and pI2-4 being expressed only in the epidermis. The ubiquitinconjugating enzyme (pI2-2) and the lipoxygenase LOX2:Hv:1 (pI8-7) are both constitutively expressed in the epidermis, and no induction could be observed (data not shown).

The cDNA clones representing the four activated genes along with the cDNAs encoding PR-1b (Gregersen et al. 1997), PR-5, PR-9, and OxOLP (Gregersen et al. 1997) were then used as probes to establish mRNA accumulation kinetics, using RNA extracted from epidermal and mesophyll tissue at different times postinoculation (p.i.) of resistant and susceptible bar- ley with fungal race UK7 (Fig. 3). As expected, $P R-1 b, P R-5$, and $P R-9$ were induced in the mesophyll, with all three genes showing a rapid and transient activation in cultivar Atlas 46, with a maximum at 24 p.i. In contrast, activation of these genes occurred later in the susceptible cultivar Atlas, in which the weak mRNA accumulation $24 \mathrm{~h}$ p.i. could not always be observed (Hahn et al. 1993).

A similar induction behavior was found for PR-10, LoxA, $S D 10$, and $\mathrm{pI}-4$, which are induced in the epidermis. In addition, these genes appear to be activated more rapidly than the mesophyll-specific genes, with substantial amounts of mRNA detectable at $18 \mathrm{~h}$ p.i. or even earlier. SD10 expression was also found in mesophyll cells of the resistant cultivar, although

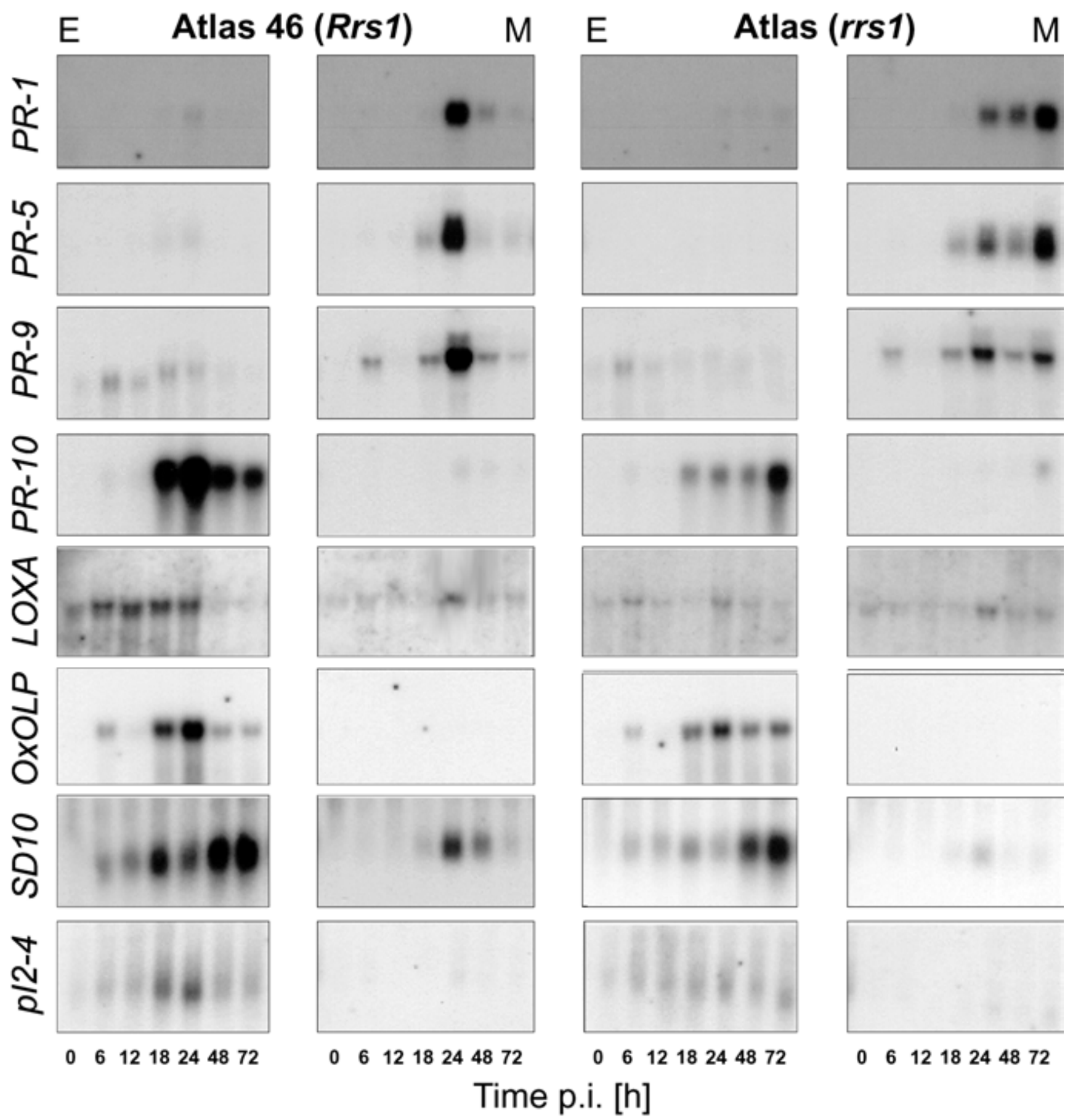

Fig. 3. RNA accumulation kinetics using epidermal (E) and mesophyll (M) RNA from leaves of cultivars Atlas 46 and Atlas 0 to 72 h p.i. with UK7 probed with eight different cDNAs encoding defense-associated proteins. All RNA was from the same infection experiment. 
later and to a lesser extent. In contrast, OxOLP mRNA accumulated in epidermal cells following the same time course in the resistant and the susceptible cultivars.

\section{Gene expression upon NIP1 treatment.}

While most of the genes analyzed are predominantly or at least more rapidly activated in resistant plants, OxOLP mRNA accumulated upon fungal infection independent of the plant resistance genotype. This prompted the question as to whether induction of the genes, with the exception of $O x O L P$, is associated with the AvrRrsl/Rrsl-encoded recognition system. Therefore, NIP1, the product of the AvrRrsl gene from $R$. secalis (Rohe et al. 1995), was used as an elicitor in expression studies. RNA was extracted from leaves $24 \mathrm{~h}$ posttreatment with NIP1 and was probed with the available cDNA clones (Fig. 4). Surprisingly, only the accumulation of the mesophyllspecific PR-1b, PR-5, and PR-9 mRNAs and of the epidermisspecific PR-10 mRNA was strongly induced by NIP1 treatment of resistant leaves. In contrast, the other mRNAs, although induced by the avirulent fungal race UK7, could not be detected upon NIP1 treatment.

\section{mRNA hybridization in situ.}

In order to complement the filter hybridization data on tissue-specific expression of defense-related genes with information on their spatial expression, in situ mRNA hybridization experiments were performed $24 \mathrm{~h}$ p.i. with spores of the fungal race UK7. As probes, antisense OxOLP mRNA was used as representative for nonspecifically occurring epidermal mRNA and antisense PR-5 mRNA as representative for a resistancespecific expressed mesophyll mRNA. The results confirmed

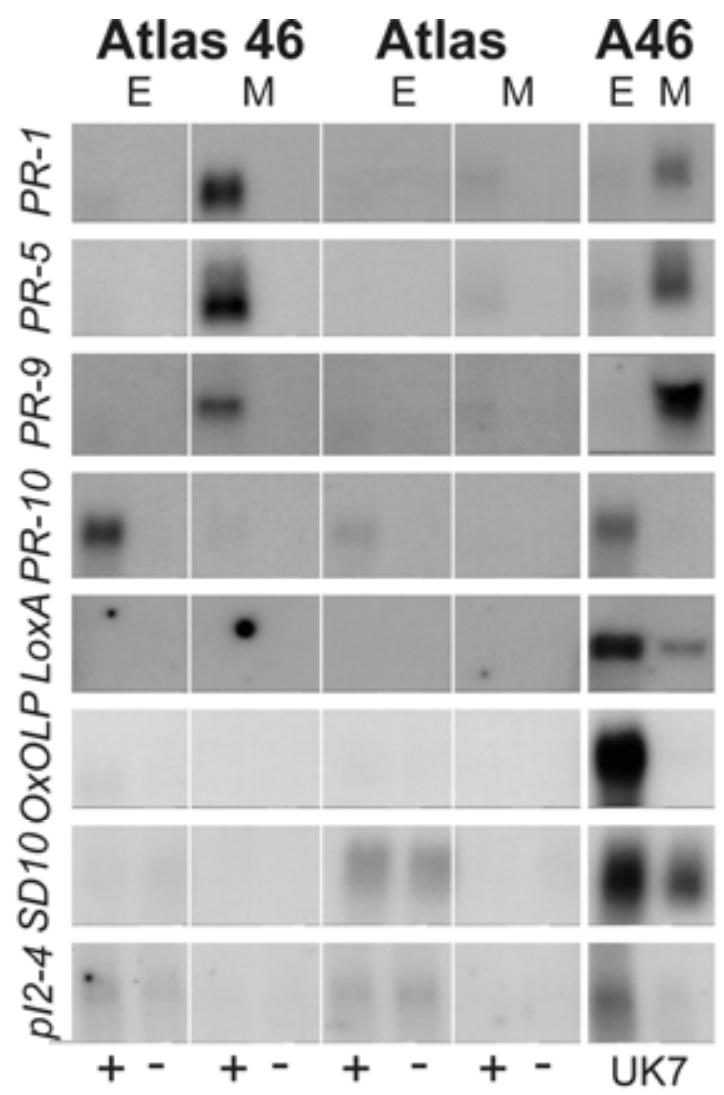

Fig. 4. Filter hybridization using epidermal (E) and mesophyll (M) RNA from leaves of cultivars Atlas 46 and Atlas $24 \mathrm{~h}$ posttreatment with NIP1 and probed with eight different cDNAs encoding defense-associated proteins. For comparison, RNA from leaves of cultivar Atlas $4624 \mathrm{~h}$ postinoculation with fungal race UK7 is shown.
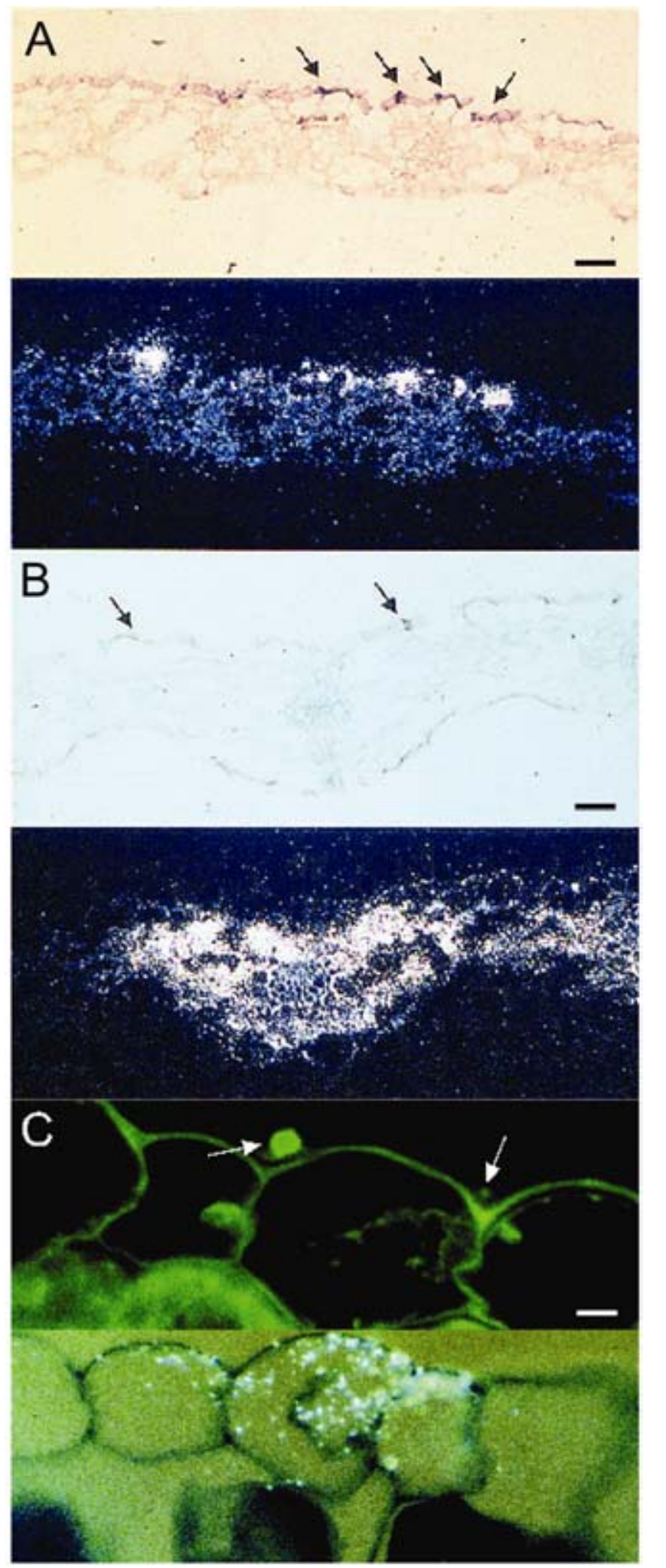

Fig. 5. In situ hybridization of leaf tissue from resistant plants $24 \mathrm{~h}$ postinoculation with fungal spores. Series of cross sections were generated that were alternately either immuno-stained using an antiserum raised against cell walls of Rhynchosporium secalis and $\mathbf{A}$, peroxidaseor B, alkaline phosphatase-coupled secondary antibodies (upper panels) or probed with $\mathbf{A}$, OxOLP, B, PR-5, and C, PR-10 antisense RNA (lower panels). Arrows indicate fungal structures. Bar $=100 \mu \mathrm{m}$ in A and $\mathrm{B}$ and $20 \mu \mathrm{m}$ in $\mathrm{C}$. 
(and expanded) the filter hybridization results. OxOLP mRNA accumulated locally at fungal penetration sites in epidermal cells of resistant and susceptible plants (Fig. 5A). In contrast, PR-5 mRNA was only detectable in leaves of the resistant cultivar (Fig. 5B). At 24 h p.i., when fungal hyphae have barely crossed the leaf cuticle (Lehnackers and Knogge 1990), only very little contact with epidermal cell walls can be expected. Surprisingly however, at this time, PR-5 mRNA was detectable already in extended areas of the mesophyll, even in cells at the distal side of the leaf. Finally, antisense PR-10 mRNA representing a resistance-specific induced epidermal gene served as a probe for in situ hybridization experiments using a different tissue fixation and embedding technique. This allowed a much improved conservation of barley leaf tissues, although at the expense of signal sensitivity. Comparable to OxOLP mRNA, PR-10 mRNA accumulated only in epidermal cells in the vicinity of fungal hyphae in resistant barley leaves (Fig. 5C).

\section{DISCUSSION}

\section{Putative function of the analyzed genes.}

When exposed to pathogens, many plants accumulate several groups of PR proteins. Although members of these groups have been shown to have antifungal activity (van Loon and van Strien 1999), in most cases the precise molecular mechanisms are not well understood (Kitajima and Sato 1999). PR-1-homologous genes exist in other organisms, and a possible mechanism for plant PR-1 may be suspected from the finding that an animal PR-1-like protein was shown to inhibit $\mathrm{Ca}^{2+}$ channel activity (Morrissette et al. 1995). PR-5 has been suggested to act by permeabilizing fungal plasma membranes. However, the plant cell walls play an important role in facilitating the toxic activity and in controlling the specificity of PR5 proteins (Ibeas et al. 2000; Selitrennikoff 2001). The PR-9 family of peroxidases is likely to be involved in the reinforcement of plant cell walls in particular by lignification in response to pathogen attack (Iiyama et al. 1994; ThordalChristensen et al. 1992). However, a more complex role of peroxidases in plant defense is suggested by the recent finding that a vacuolar isoform may represent a susceptibility factor in barley. Transient expression of peroxidase Prx7 increased the colonization efficiency of $B$. graminis f. sp. hordei, an effect that required the presence of the vacuolar targeting signal but not full enzyme activity (Kristensen et al. 2001). Finally, the function of the intracellular PR-10 family has been under debate. It was proposed, however, that at least some of the family members possess ribonuclease activity (Moiseyev et al. 1997; Walter et al. 1996), and recently, a PR-10-like protein from lupin was demonstrated to belong to the class II ribonucleases (Bantignies et al. 2000). Along with additional antifungal proteins, these PR proteins are part of the repertoire of plant effector molecules synthesized locally as well as systemically upon infection (Selitrennikoff 2001).

OxOLP as well as OxO belong to a group of proteins named after germin, an enzyme generating $\mathrm{H}_{2} \mathrm{O}_{2}$ (Bernier and Berna 2001). While OxO oxidizes oxalate, this activity could not be detected in OxOLP. Instead, OxOLP may generate $\mathrm{H}_{2} \mathrm{O}_{2}$ from an as yet unidentified substrate (Wei et al. 1998). Alternatively, the protein may have superoxide dismutase (SOD) activity, as a germin-like, extracellular protein from the moss Barbula unguiculata (Yamahara et al. 1999) and the major tobacco nectar protein nectarin I (Carter and Thornburg 2000) were both identified to be Mn-containing SODs. In addition, germin itself was recently shown to be a Mn-containing protein with both OxO and SOD activity (Woo et al. 2000). Should barley OxOLP have SOD activity and thus require superoxide anions $\left({ }^{\circ} \mathrm{O}_{2}^{-}\right.$) as substrates, this would suggest a second $\mathrm{H}_{2} \mathrm{O}_{2}$-generat- ing system that probably involves NADPH oxidase activity to provide ${ }^{\circ} \mathrm{O}_{2}^{-}$(Wojtaszek 1997).

In search for additional genes that are specifically induced in the epidermis of Rrsl-resistant barley plants upon infection with $R$. secalis, the gene encoding a PR-10-type protein was identified for the first time in barley, along with a gene of unknown function, $p I 2-4$. The deduced pI2-4 protein shows structural homology with VfENOD18 from Vicia faba (Hohnjec et al. 2000), with products of ESTs from A. thaliana, rice, and maize, and with members of the bacterial MJ0577 protein superfamily. For the bacterial MJ0577 protein, a function as ATPase or ATP-mediated molecular switch was suggested (Zarembinski et al. 1998). In addition, two genes were found, LoxA and SD10, which were already known from barley, however not as being associated with the resistance response. LoxA encodes barley LOX1 (van Mechelen et al. 1999), a 9-lipoxygenase that may be involved in the synthesis of $\mathrm{C}_{6}$-volatiles (Bate and Rothstein 1998). SD10 has highest homologies to members of the chymotrypsin inhibitor family in barley endosperm (Jakobsen et al. 1991; Williamson et al. 1987). 9Lipoxygenase and proteinase inhibitors would be expected to participate in the plant wound response, such as herbivore damage, rather than in disease resistance (Koch et al. 1999). However, a protein homologous to barley SD10, MPI, was expressed in maize, not only upon wounding but also upon fungal infection (Cordero et al. 1994). Furthermore, several defenserelated genes were enhanced during senescence (BuchananWollaston and Ainsworth 1997; Butt et al. 1998; Hanfrey et al. 1996). In addition, a comparison of the tomato race-specific resistance and wound responses based on cDNA amplified fragment length polymorphism revealed a striking overlap in the gene expression profiles (Durrant et al. 2000). These data indicate that there are common steps in the signaling pathways of the wound, senescence, and resistance responses of plants.

\section{Tissue-specific expression of defense-associated genes.}

Infection of barley with the obligate biotroph B. graminis, which directly infects the leave epidermis by forming haustoria within this cellular layer, has been shown to cause differential gene induction in epidermis and mesophyll. In barley lines differing in the resistance genes $\mathrm{Ml}-a \mathrm{l}$ and $\mathrm{Ml}-a 3$, infection with virulent and avirulent powdery mildew isolates led to the activation of defense-associated genes independent of the interaction type, even with a tendency toward stronger transcript accumulation in susceptible plants (Gregersen et al. 1997). Most genes were activated in the mesophyll, although the fungus never directly contacts this tissue. These results were therefore interpreted as reflecting a general defense response of barley, rather than a specific response against $B$. graminis (Gregersen et al. 1997). It remains unclear which reactions specify resistance to $B$. graminis and what role the epidermis has in determining specificity.

The necrotrophic fungus $R$. secalis also interacts directly with the epidermis of barley leaves, not through formation of haustoria, however, but by growing extracellularly beneath the leaf cuticle. Resistance to $R$. secalis does not involve a hypersensitive response. However, in barley plants expressing Rrs 1 mediated resistance, the mesophyll-specific $P R-5$ and $P R-9$ genes are rapidly and transiently activated by avirulent fungal strains as well as by NIP1, the product of the fungal avirulence gene AvrRrsl (Hahn et al. 1993; Rohe et al. 1995). This early transcript accumulation, which cannot be observed in the compatible interaction, is followed by a second increase in gene expression that also occurs in susceptible plants.

When the expression of defense-related proteins was analyzed in epidermis and mesophyll tissues upon inoculation with spores of $R$. secalis, the observed patterns of gene activa- 
tion fell into four groups: i) resistance specificity in the mesophyll $(P R-1 b, P R-5, P R-9)$, ii) resistance specificity in the epidermis ( $P R-10, \operatorname{LoxA}, p I 2-4)$, iii) resistance specificity preferentially but not exclusively in the epidermis ( $S D 10)$, and iv) nonspecificity in the epidermis $(O x O L P)$. Taking the slow development of $R$. secalis on the host into account, the observed timing of mRNA accumulation must be considered as very rapid, with gene activation in the epidermis preceding that in the mesophyll. Furthermore, there is a drastic difference in spatial gene expression in the two tissues. The epidermisspecific mRNAs accumulate locally in cells near fungal penetration sites, whereas the mesophyll-specific mRNAs occur in extended leaf regions.

The product of the fungal avirulence gene AvrRrs1, NIP1 (Rohe et al. 1995), would be expected to elicit all reactions relevant to Rrs 1 -mediated plant resistance. In contrast, the nonspecific induction of the OxOLP gene independent of the presence of the Rrsl gene suggests a more general function of the gene product, precluding its elicitation by NIP1. Surprisingly however, only the PR protein-encoding genes, including the epidermis-specific $P R-10$ gene, were activated by NIP1 in leaves of Rrsl barley. Not only $O x O L P$, but also genes LoxA, SD10, and pI2-4, although induced by the fungus, are not activated by the avirulence determinant. However, $O x O L P$ and $S D 10$ are weakly induced in resistant and susceptible plants by a fungal strain lacking the NIPl gene. The results suggest that an additional elicitor is responsible for the activation of these genes and that NIP1, although alone unable to induce their expression, enhances gene expression in resistant plants.

\section{Intertissue signaling between epidermis and mesophyll.}

Based on the differential accumulation of defense-associated transcripts in $\mathrm{Ml}$ - $\mathrm{al}$ and $\mathrm{Ml}$-a3 barley epidermis and mesophyll tissues upon infection with the powdery mildew fungus, $B$. graminis f. sp. hordei and on the subcellular localization of $\mathrm{H}_{2} \mathrm{O}_{2}$ in $\mathrm{Ml}$ - $a 3$-mediated resistance (Thordal-Christensen et al. 1997), a model was proposed for part of the early signaling processes occurring between epidermis and mesophyll cells (Gregersen et al. 1997). The model assumes a penetrationinduced acidification of the apoplast between epidermis and mesophyll cells by activation of the plasma membrane $\mathrm{H}^{+}$ATPase. At low $\mathrm{pH}$, the extracellular mesophyll $\mathrm{OxO}$ is active and generates $\mathrm{H}_{2} \mathrm{O}_{2}$, which acts as a signal that triggers the hypersensitive response in penetrated epidermis cells (Zhou et al. 1998; 2000). Activation of the barley $\mathrm{H}^{+}$-ATPase upon inoculation with powdery mildew is proposed to occur through the activity of a 14-3-3 protein that was recently shown to interact with the membrane enzyme, using the yeast two-hybrid system (Finnie et al. 2002).

Also the barley-R. secalis interaction appears to involve a cross-talk between epidermis and mesophyll. Evidence for this intertissue signaling comes from preliminary studies using mesophyll tissue that was separated from the epidermis using pectinases. Neither upon infection with avirulent $R$. secalis nor upon treatment with NIP1 was PR-5 mRNA accumulation observed (K. Toth-Sagi and W. Knogge, unpublished data), indicating that the mesophyll cells do not directly perceive NIP1. An as yet unknown epidermisderived signal appears to be involved, which is drastically amplified, thus causing PR-5 synthesis in extended regions of the mesophyll. It remains to be shown, however, whether $\mathrm{H}_{2} \mathrm{O}_{2}$ is the signal that triggers the mesophyll cell response, as indicated in the powdery mildew model (Zhou et al. 2000). Indirect evidence for the occurrence of $\mathrm{H}_{2} \mathrm{O}_{2}$ comes from the observation that, $24 \mathrm{~h}$ p.i. only in incompatible interactions, the enzymatic separation of epidermis and mesophyll is no longer possible. This indicates the cross-linking of cell wall constituents between both tissues, which would require $\mathrm{H}_{2} \mathrm{O}_{2}$. A signaling function of $\mathrm{H}_{2} \mathrm{O}_{2}$ may also be concluded from the accumulation of PR-5 mRNA upon spraying of barley leaves with $\mathrm{H}_{2} \mathrm{O}_{2}$. However, this gene induction occurred to a similar extent in resistant as well as in susceptible plants (data not shown). The decisive process for the defense response of the mesophyll to occur may, therefore, be whether $\mathrm{H}_{2} \mathrm{O}_{2}$ is generated or not upon fungal attack. This points the attention to one or more $\mathrm{H}_{2} \mathrm{O}_{2}$-generating systems. The role of the extracellular OxOLP that is induced in the epidermis of resistant and susceptible plants remains obscure. Although it may be part of an $\mathrm{H}_{2} \mathrm{O}_{2}$-generating system, its synthesis independent of the plant resistance genotype precludes its induction by NIP1 as well as its exclusive role in resistance and, instead, suggests the involvement of an additional factor.

Alternatively, $\mathrm{H}_{2} \mathrm{O}_{2}$ may be produced by $\mathrm{OxO}$, which is located in the cell walls of the mesophyll tissue (Zhou et al. 1998, 2000). It is tempting to adopt the cell wall acidification model proposed in the powdery mildew system (Zhou et al. 2000 ) in particular, because two secreted proteins from $R$. secalis, NIP1 and NIP3, have been shown to stimulate the activity of the plasma membrane-localized $\mathrm{H}^{+}$-ATPase (Wevelsiep et al. 1993). However, this stimulation is also independent of the plant resistance genotype, therefore rendering it unlikely to be the crucial step in the process that leads to the mesophyll response.

The rapid and strong induction of the $P R-10$ gene in the epidermis of resistant leaves demonstrates that resistance specificity is determined in the outer leaf cell layer. The $P R-10$ gene product is unlikely to be involved in stimulating the mesophyll response. Its $R r s 1$-specific induction upon fungal infection as well as upon NIP1 treatment may imply, however, that other resistance-specific reactions can be expected in this tissue, which eventually may lead to the unraveling of the signaling pathway between the leaf tissues.

Two conclusions can be drawn from the presented findings. i) The presence of the avirulence determinant NIP1 is specifically recognized by the epidermis cells as well as by the mesophyll cells. The epidermis cells are likely to interact directly with NIP1 secreted by the fungus. In contrast, the mesophyll response may be triggered by a secondary signal that is generated as part of the defense response of the epidermis. ii) The NIP1 nonresponsive genes are not at all or only in conjunction with the NIP1-activated genes relevant to the defense against $R$. secalis, and different subsets of genes are induced by one or more as yet unknown elicitors upon fungal infection.

\section{MATERIALS AND METHODS}

Plant and fungal material, leaf treatments, cDNA clones.

Origin of barley cultivars Atlas $46(\operatorname{Rrs} 1)$ and Atlas ( $r r s 1)$ and of $R$. secalis race UK7 as well as culture conditions and isolation of fungal spores have been previously described (Lehnackers and Knogge 1990). All experiments were carried out using 7-day-old primary leaves. For spray inoculation, 200 $\mu \mathrm{l}$ per leaf of a suspension of $10^{6}$ spores per $\mathrm{ml}$ in $0.05 \%$ (vol/vol) Tween-20 was used. For NIP1 treatment (Hahn et al. 1993), recombinant NIP1 expressed in E. coli (Gierlich et al. 1999) was applied to the abaxial side of leaves by attaching 15$\mu \mathrm{l}$ droplets containing $20 \mathrm{ng}$ of NIP1 per $\mu \mathrm{l}$ in $0.05 \%$ (vol/vol) Tween-20. As a control, leaves were treated with $15 \mu \mathrm{l} 0.05 \%$ (vol/vol) Tween-20. The cDNA clones pHvPR-1b and pBH6301 (PR-1b, PR-9) (Gregersen et al. 1997) and pBH6-903 (OxOLP) (Wei et al. 1998) were provided by H. ThordalChristensen and D. Collinge, The Royal Veterinary and Agricultural University, Copenhagen, Denmark. 


\section{Extraction of RNA from different leaf tissues.}

The abaxial epidermal layer of primary leaves was mechanically peeled off (Knogge et al. 1981). Since the residual leaves consist predominantly of mesophyll cells (in addition to the vascular tissue and the adaxial epidermis), this material will be referred to as mesophyll. Total RNA was extracted $24 \mathrm{~h}$ p.i. or after treatment by the guanidinium hydrochloride method (Logemann et al. 1987). RNA concentrations were determined spectrometrically (Sambrook et al. 1989).

\section{RMDD.}

For cDNA synthesis, mRNA was isolated from $30 \mu \mathrm{g}$ of DNase-treated leaf RNA by use of oligo(dT) Dynabeads (Dynal, Oslo, Norway). The eluted mRNA was combined with 0.6 $\mu \mathrm{l} 20 \mathrm{mM} \mathrm{MgCl}, 0.5 \mu \mathrm{l} 4 \mu \mathrm{M}$ cDNA primer CP29V (ACCTACGTGCAGAT $_{(15)} \mathrm{V}$, with $\mathrm{V}$ representing a mixture of $\mathrm{A}, \mathrm{C}$, and G), $1 \mu \mathrm{l} 100 \mathrm{mM}$ DTT, and $6 \mu \mathrm{l}$ of "Time Saver" firststrand reaction mix (Amersham-Pharmacia, Freiburg, Germany) in a total volume of $18 \mu \mathrm{l}$. After incubating the reaction mixture for $1 \mathrm{~h}$ at $37^{\circ} \mathrm{C}, 33 \mu \mathrm{l}$ of second-strand reaction mix were added, and the incubation was continued for $30 \mathrm{~min}$ at $12^{\circ} \mathrm{C}$, followed by $1 \mathrm{~h}$ at $22^{\circ} \mathrm{C}$. cDNAs were diluted with $25 \mu \mathrm{l}$ of water, were heated for $10 \mathrm{~min}$ at $65^{\circ} \mathrm{C}$, and were extracted once with phenol and once with chloroform. Primers were removed, using a Chromaspin 1000 column (Clontech Laboratories, Heidelberg, Germany) according to the manufacturer's instructions. Eluted cDNA $(10 \mu \mathrm{l})$ in a total volume of $20 \mu \mathrm{l}$ of $1 \times$ reaction buffer was combined with 1 U of Sau3A (Roche, Grenzach-Wyhlen, Germany) and was incubated $1 \mathrm{~h}$ at $37^{\circ} \mathrm{C}$. The enzyme was removed by extraction with phenol and chloroform, nucleic acids were precipitated, and the pellet was dissolved in $7 \mu \mathrm{l}$ of $1 \times$ DNA dilution buffer from the Rapid DNA Ligation Kit (Roche). After addition of $1 \mu \mathrm{g}$ of NdeII (Sau3A) linker ML2025 (prepared from oligos ML20, TCACATGCTAAGTCTCGCGA, and LM25, GATCTCGCGAGACTTAGCATGTGAC, as previously described [Fischer et al. 1995]), $10 \mu \mathrm{l}$ of rapid ligation buffer, and 1 $\mu \mathrm{l}$ of T4 DNA ligase (Rapid DNA Ligation Kit, Roche), ligation was performed for $1 \mathrm{~h}$ at room temperature. To block $3^{\prime}$ ends against extension, entire ligation reactions were combined with $10 \mu \mathrm{l} 10 \times$ PCR buffer (0.5 KCl, 0.1 M Tris/HCl, $\mathrm{pH} 8.3), 5 \mu \mathrm{l}$ of $1 \mathrm{mM}$ ddNTPs, $6 \mu \mathrm{l}$ of $50 \mathrm{mM} \mathrm{MgCl} 2,1 \mathrm{U}$ of AmpliTaq polymerase (Perkin-Elmer, Rodgau-Jügesheim, Germany), and 58.5 $\mu \mathrm{l}$ of water. After initial denaturation for $1 \mathrm{~min}$ at $95^{\circ} \mathrm{C}$ followed by another $20 \mathrm{~s}$ at $95^{\circ} \mathrm{C}$, reactions were cooled to $72^{\circ} \mathrm{C}$, applying a slope of $-0.2^{\circ} \mathrm{C}$ per $\mathrm{s}$, and were held at this temperature for 20 $\mathrm{s}$. The sequence of denaturation, slow cooling, and dideoxynucleotide incorporation was repeated for 10 cycles. Nucleotides were then removed using QiaQuick spin columns (Qiagen, Hilden, Germany). For amplification, one out of $50 \mu \mathrm{l}$ each of purified, end-blocked ligation products was combined with $2 \mu \mathrm{l}$ of $10 \times$ PCR buffer, $1 \mu \mathrm{l}$ of $1 \mathrm{M}$ tetramethyl ammonium chloride (Fluka, New Ulm, Germany), $0.4 \mu \mathrm{l}$ of $10 \mathrm{mM}$ dNTPs, 1.5 $\mu \mathrm{l}$ of $20 \mathrm{mM} \mathrm{MgCl} 2,2 \mu \mathrm{l}$ each of $4 \mu \mathrm{M}$ first-round PCR primers CP29X (ACCTACGTGCAGAT ${ }_{(15)} \mathrm{X}$, with $\mathrm{X}$ representing either A, C, or G) and ML24Z (TCACATGCTAACTCTCGCGAGATCZ, with Z representing either A, C, G, or T), $8.9 \mu \mathrm{l}$ of water, and $0.2 \mu \mathrm{l}(1 \mathrm{U})$ AmpliTaq polymerase. The cycling program consisted of $20 \mathrm{~s}$ at $94^{\circ} \mathrm{C}, 20 \mathrm{~s}$ at $60^{\circ} \mathrm{C}$, and $3 \mathrm{~min}$ at $72^{\circ} \mathrm{C}$, repeated 30 times. Reaction products were diluted 1:100 with $10 \mathrm{mM}$ Tris/ $1 \mathrm{mM}$ EDTA, $\mathrm{pH} 8.0$, and $2 \mu \mathrm{l}$ of each was subjected to 20 additional amplification cycles, using the second round primers CP29VX (ACCTACGTGCAGAT ${ }_{(15)} \mathrm{VZ}$, with $\mathrm{V}$ representing a mixture of $\mathrm{A}, \mathrm{C}$, and $\mathrm{G}$, and $\mathrm{Z}$ representing either A, C, G, or T) and Bio-ML24NZ (TCACATGCTAACTCTCGCGAGATCNZ, with $\mathrm{N}$ representing a mixture of $\mathrm{A}, \mathrm{C}, \mathrm{G}$, and $\mathrm{T}$, and $\mathrm{Z}$ representing either $\mathrm{A}, \mathrm{C}, \mathrm{G}$, or $\mathrm{T}$; primers are biotinylated at the $5^{\prime}$ end). After checking on an agarose gel, reactions were diluted with 1 vol of $99 \%$ formamide containing $5 \mathrm{mM}$ EDTA, $0.1 \%$ bromophenol blue, and $0.1 \%$ xylene cyanol and were loaded onto a preheated denaturing $4.5 \%$ polyacrylamide gel mounted on a GATC1500 direct blotting electrophoresis apparatus (GATC, Konstanz, Germany). Electrophoresis was carried out for $4 \mathrm{~h}$ at $30 \mathrm{~W}$ with the conveyor belt (after a prerun period of $45 \mathrm{~min}$ ) set to an initial speed of 16 $\mathrm{cm} / \mathrm{h}$, slowing to $10 \mathrm{~cm} / \mathrm{h}$ at the end. Membranes were air-dried, were gently UV-fixed $\left(10,000 \mu \mathrm{W} / \mathrm{cm}^{2}\right)$ in a Stratalinker (Stratagene, Heidelberg, Germany), and were developed using standard, streptavidin/alkaline phosphatase/NBT/BCIP-based detection chemistry (Roche). Bands of interest were cut out of the wet membranes. After transferring $1 / 2$ a band to a PCR mixture as above, re-amplification was performed for 25 cycles. After one round of gel purification using the GATC1500 blotter (GATC), bands were subjected to direct sequencing on an automated sequencer (PE/Abi PRISM 377, Applied Biosystems, Foster City, CA, U.S.A.).

\section{Molecular techniques.}

Total RNA ( 5 to $15 \mu \mathrm{g}$ ) were separated on $1.2 \%$ agarose gels containing $0.65 \%$ formaldehyde (Sambrook et al. 1989), were transferred to nylon membranes (Roche), and were hybridized with ${ }^{32}$ P-labeled probes, using the Random Primed DNA Labeling Kit (Roche). Prehybridization and hybridization were carried out at $65^{\circ} \mathrm{C}$ in $10 \%$ (wt/vol) dextransulfate, $1 \mathrm{M} \mathrm{NaCl}, 1 \%$ (wt/vol) sodium dodecyl sulfate (SDS), and $100 \mu \mathrm{g}$ of salmon sperm DNA per ml. After hybridization overnight, filters were washed twice for $20 \mathrm{~min}$ in $2 \times \mathrm{SSC}(1 \times \mathrm{SSC}$ is $0.15 \mathrm{M} \mathrm{NaCl}$ plus $0.015 \mathrm{M}$ sodium citrate) and $0.1 \%$ (wt/vol) SDS at $65^{\circ} \mathrm{C}$.

For construction of a cDNA library, total RNA from UK7infected leaves of cultivar Atlas 46 was extracted $24 \mathrm{~h}$ p.i. and poly $(\mathrm{A})^{+}$-RNA was isolated, using oligo $(\mathrm{dT})_{25}$-coated Dynabeads (Dynal). cDNAs were prepared and cloned into the $\lambda$-UniZAP vector system (Stratagene), according to the manufacturer's instructions. The library was screened using the reamplified PCR products obtained by RMDD. Hybridization and washing conditions were as described for filter hybridization. DNA excised as pBluescript II SK(+) plasmid clones was sequenced by automated sequencing using a PE/Abi PRISM 377 (Applied Biosystems).

\section{Hybridization in situ.}

Hybridization in situ using radioactively labeled probes was carried out as previously described (Schmelzer et al. 1989). Fungal structures were stained using an antiserum raised against $R$. secalis cell walls (Lehnackers and Knogge 1990) and peroxidase- or alkaline phosphatase-conjugated secondary antibodies. To obtain an improved preservation of leaf tissues, an acrylic resin embedding system (Cenacchi et al. 1993; Scala et al. 1992) was used in conjunction with a silver-enhanced immunogold labeling technique to visualize accumulated mRNAs. For this purpose, fixation of leaf material was performed as previously described for immunochemical staining (Lehnackers and Knogge 1990). After dehydration, leaf pieces were incubated three times for $2 \mathrm{~h}$ in $100 \%$ ethanol/Unicryl (1:1) (British BioCell, Cardiff, U.K.), and subsequently were infiltrated twice for $12 \mathrm{~h}$ with the resin alone. Polymerization was carried out at $-20^{\circ} \mathrm{C}$ for $72 \mathrm{~h}$ under UV light. Sections (4 $\mu \mathrm{m})$ were cut using a glass knife, were collected on BioBond coated slides (British BioCell), and were air-dried at $40^{\circ} \mathrm{C}$. The sections were then treated for $30 \mathrm{~min}$ with $0.2 \mathrm{M} \mathrm{HCl}$ at room temperature, twice for $5 \mathrm{~min}$ with $\mathrm{PBS}$, for $20 \mathrm{~min}$ with 250 $\mu \mathrm{g} / \mathrm{ml}$ of proteinase $\mathrm{K}$ in $50 \mathrm{mM}$ Tris- $\mathrm{HCl}(150 \mathrm{mM} \mathrm{NaCl}, 2$ $\mathrm{mM} \mathrm{CaCl} 2$ ), $\mathrm{pH} 7.5$, were washed in $0.1 \mathrm{M} \mathrm{K}$ phosphate buffer, $\mathrm{pH} \mathrm{7,} \mathrm{and} \mathrm{were} \mathrm{fixed} \mathrm{for} 20 \mathrm{~min}$ in the fixative. The slides were air-dried and kept at least overnight. 
Probes for hybridization were prepared according to the digoxigenin (DIG)-RNA labeling method (Roche). The probe length was reduced to approximately $200 \mathrm{nt}$ by limited alkaline hydrolysis of the transcripts (Cox et al. 1984). For hybridization in situ (Schmelzer et al. 1989), sections were covered with $10 \mu \mathrm{l}$ of hybridization buffer containing $10 \mathrm{ng}$ of DIG-labeled sense or antisense in vitro transcripts. Cover slips $(18 \times 18$ $\mathrm{mm}$ ) were placed on the sections, and the edges were sealed with rubber cement (Fixogum, Marabuwerke, Tamm, Germany). The slides were incubated in a moist chamber at $50^{\circ} \mathrm{C}$ overnight. After cautious removal of cover slips, the slides were washed at $45^{\circ} \mathrm{C}$ (once for $30 \mathrm{~min}$, twice for $45 \mathrm{~min}$ ) in $1 \times \mathrm{SSC}$ (50\% formamide). Treatment at $37^{\circ} \mathrm{C}$ for $30 \mathrm{~min}$ with $20 \mu \mathrm{g} / \mathrm{ml}$ RNase A (Roche) in $10 \mathrm{mM}$ Tris- $\mathrm{HCl}(0.5 \mathrm{M} \mathrm{NaCl}, 1 \mathrm{mM}$ EDTA), pH 8.0, was followed by washing at $45^{\circ} \mathrm{C}$ (twice for $45 \mathrm{~min}$ ) with $1 \times \mathrm{SSC}$ ( $50 \%$ formamide), at room temperature (twice for $5 \mathrm{~min}$ ) in $1 \times \mathrm{SSC}$ and in PBS (twice for $5 \mathrm{~min}$ ). For detection of DIG-labeled probes, gold-conjugated $(5 \mathrm{~nm})$ anti-DIG antibodies were used according to the manufacturer's protocol (Roche). Immunogold labels were amplified using the LM/SM Silver Enhancing kit (British BioCell). After brief counter-staining of the tissue with $0.05 \%$ (wt/vol) toluidine blue in $0.1 \mathrm{M} \mathrm{Na}$ acetate buffer, $\mathrm{pH} 4.5$, the gold and silverenhanced signal was visualized under epipolarized light.

\section{ACKNOWLEDGMENTS}

The authors are grateful to $\mathrm{H}$. Thordal-Christensen and D. Collinge, Copenhagen, Denmark, for providing the PR-1b, PR-9, and OxOLP cDNA clones. The work was supported by a research grant to W. Knogge and a research scholarship to S. Steiner-Lange from the Deutsche Forschungsgemeinschaft as well as by a grant from the State of NorthrhineWestfalia to H. L.

\section{LITERATURE CITED}

Bantignies, B., Seguin, J., Muzac, I., Dedaldechamp, F., Gulick, P., and Ibrahim, R. 2000. Direct evidence for ribonucleolytic activity of a PR10-like protein from white lupin roots. Plant Mol. Biol. 42:871-881.

Bate, N. J., and Rothstein, S. J. 1998. C6-volatiles derived from the lipoxygenase pathway induced a subset of defense-related genes. Plant J. 16:561-569.

Bernier, F., and Berna, A. 2001. Germins and germin-like proteins: Plant do-all proteins. But what do they do exactly? Plant Physiol. Biochem. 39:545-554.

Bieza, K., and Lois, R. 2001. An Arabidopsis mutant tolerant to lethal ultraviolet-B levels shows constitutively elevated accumulation of flavonoids and other phenolics. Plant Physiol. 126:1105-1115.

Buchanan-Wollaston, V., and Ainsworth, C. 1997. Leaf senescence in Brassica napus: Cloning of senescence related genes by subtractive hybridisation. Plant Mol. Biol. 33:821-834.

Butt, A., Mousley, C., Morris, K., Beynon, J., Can, C., Holub, E., T., G. J., and Buchanan-Wollaston, V. 1998. Differential expression of a senescence-enhanced metallothionein gene in Arabidopsis in response to isolates of Peronospora parasitica and Pseudomonas syringae. Plant J. 16:209-221.

Carpita, N. C., and Gibeaut, D. M. 1993. Structural models of primary cell walls in flowering plants: Consistency of molecular structure with the physical properties of the walls during growth. Plant J. 3:1-30.

Carter, C., and Thornburg, R. W. 2000. Tobacco nectarin I-Purification and characterization as a germin-like, manganese superoxide dismutase implicated in the defense of floral reproductive tissues. J. Biol. Chem. 275:36726-36733.

Cenacchi, G., Musiani, M., Gentilomi, G., Righi, S., Zerbini, M., Chandler, J. G., Scala, C., La Placa, M., and Martinelli, G. N. 1993. In situ hybridization at the ultrastructural level: Localization of cytomegalovirus DNA using digoxigenin labeled probes. J. Submicros. Cytol. Pathol. 25:341-345.

Christensen, A. B., Cho, B. H., Naesby, M., Gregersen, P. L., Brandt, J., Madriz-Ordenana, K., Collinge, D. B., and Thordal-Christensen, H. 2002. The molecular characterization of two barley proteins establishes the novel PR-17 family of pathogenesis-related proteins. Mol. Plant Pathol. 3:135-144.

Cordero, M. J., Raventós, D., and San Segundo, B. 1994. Expression of a maize proteinase inhibitor gene is induced in response to wounding and fungal infection: Systemic wound-response of a monocot gene. Plant J. 6:141-150.

Cox, K. H., DeLeon, D. V., Angerer, L. M., and Angerer, R. C. 1984. Detection of mRNAs in sea urchin embryos by in situ hybridization using asymmetric RNA probes. Dev. Biol. 101:485-502.

Durrant, W. E., Rowland, O., Piedras, P., Hammond-Kosack, K. E., and Jones, J. D. G. 2000. cDNA-AFLP reveals a striking overlap in racespecific resistance and wound response gene expression profiles. Plant Cell 12:963-977.

Facchini, P. J., Hagel, J., and Zulak, K. G. 2002. Hydroxycinnamic acid amide metabolism: Physiology and biochemistry. Can. J. Botany-Rev. Can. Botanique 80:577-589.

Finnie, C., Andersen, C. H., Borch, J., Gjetting, S., Christensen, A. B., de Boer, A. H., Thordal-Christensen, H., and Collinge, D. B. 2002. Do 14-3-3 proteins and plasma membrane $\mathrm{H}^{+}$-ATPases interact in the barley epidermis in response to the barley powdery mildew fungus? Plant Mol. Biol. 49:137-147.

Fischer, A., Saedler, H., and Theissen, G. 1995. Restriction fragment length polymorphism-coupled domain-directed differential display: A highly efficient technique for expression analysis of multigene families. Proc. Nat. Acad. Sci. U.S.A. 92:5331-5335.

Gierlich, A., van't Slot, K. A. E., Li, V. M., Marie, C., Hermann, H., and Knogge, W. 1999. Heterologous expression of the avirulence gene product, NIP1, from the barley pathogen Rhynchosporium secalis. Prot. Expr. Purif. 17:64-73.

Gregersen, P. L., Thordal-Christensen, H., Foerster, H., and Collinge, D. B. 1997. Differential gene transcript accumulation in barley leaf epidermis and mesophyll in response to attack by Blumeria graminis $\mathrm{f}$. sp. hordei (syn. Erysiphe graminis f. sp. hordei). Physiol. Mol. Plant Pathol. 51:85-97.

Hahn, M., Jüngling, S., and Knogge, W. 1993. Cultivar-specific elicitation of barley defense reactions by the phytotoxic peptide NIP1 from Rhynchosporium secalis. Mol. Plant-Microbe Interact. 6:745-754.

Hanfrey, C., Fife, M., and Buchanan-Wollaston, V. 1996. Leaf senescence in Brassica napus: Expression of genes encoding pathogenesis-related proteins. Plant Mol. Biol. 30:597-609.

Hohnjec, N., Küster, H., Albus, U., Frosch, S. C., Becker, J. D., Pühler, A., Perlick, A. M., and Frühling, M. 2000. The broad bean nodulin VfENOD18 is a member of a novel family of plant proteins with homologies to the bacterial MJ0577 superfamily. Mol. Gen. Genet. 264:241-250.

Ibeas, J. I., Lee, H., Damsz, B., Prasad, D. T., Pardo, J. M., Hasegawa, P. M., Bressan, R. A., and Narasimhan, M. L. 2000. Fungal cell wall phosphomannans facilitate the toxic activity of a plant PR-5 protein. Plant J. 23:375-383.

Iiyama, K., Lam, T. B.-T., and Stone, B. A. 1994. Covalent cross-links in the cell wall. Plant Physiol. 104:315-320.

Jakobsen, K. S., Kalvenes, C., and Olsen, O. A. 1991. mRNA levels in the developing aleurone and starchy endosperm in wild type and a high lysine (lys 3a) mutant of barley. Physiol. Plant. 83:201-208.

Kitajima, S., and Sato, F. 1999. Plant pathogenesis-related proteins: Molecular mechanisms of gene expression and protein function. J. Biochem. 125:1-8.

Kleber-Janke, T., and Krupinska, K. 1997. Isolation of cDNA clones for genes showing enhanced expression in barley leaves during dark-induced senescence as well as during senescence under field conditions. Planta 203:332-340.

Knogge, W., and Weissenböck, G. 1986. Tissue-distribution of secondary phenolic biosynthesis in developing primary leaves of Avena sativa. Planta 167:196-205.

Knogge, W., Beulen, C., and Weissenböck, G. 1981. Distribution of phenylalanine ammonia-lyase and 4-coumarate:CoA ligase in oat primary leaf tissues. Z. Naturforsch. 36c:389-395.

Koch, T., Krumm, T., Jung, V., Engelberth, J., and Boland, W. 1999. Differential induction of plant volatile biosynthesis in the lima bean by early and late intermediates of the octadecanoid-signaling pathway. Plant Physiol. 121:153-162.

Kristensen, B. K., Ammitzbøll, H., Rasmussen, S. K., and Nielsen, K. A. 2001. Transient expression of a vacuolar peroxidase increases susceptibility of epidermal barley cells to powdery mildew. Mol. Plant Pathol. 2:311-317.

Lehnackers, H., and Knogge, W. 1990. Cytological studies on the infection of barley cultivars with known resistance genotypes by Rhynchosporium secalis. Can. J. Botany 68:1953-1961.

Lo, S.-C. C., and Nicholson, R. L. 1998. Reduction of light-induced anthocyanin accumulation in inoculated sorghum mesocotyls. Implications for a compensatory role in the defense response. Plant Physiol. 116:979-989.

Lo, S.-C. C., Hipskind, J. D., and Nicholson, R. L. 1999. cDNA cloning 
of a sorghum pathogenesis-related protein (PR-10) and differential expression of defense-related genes following inoculation with Cochliobolus heterostrophus or Colletotrichum sublineolum. Mol. PlantMicrobe Interact. 12:479-489.

Logemann, J., Schell, J., and Willmitzer, L. 1987. Improved method for the isolation of RNA from plant tissues. Anal. Biochem. 163:16-20.

Midoh, N., and Iwata, M. 1996. Cloning and characterization of a probenazole-inducible gene for an intracellular pathogenesis-related protein in rice. Plant Cell Physiol. 37:9-18.

Moiseyev, G. P., Fedoreyeva, L. I., Zhuravlev, Y. N., Yasnetskaya, E., Jekel, P. A., and Beintema, J. J. 1997. Primary structures of two ribonucleases from ginseng calluses: New members of the PR-10 family of intracellular pathogenesis-related plant proteins. FEBS (Fed. Eur. Biochem. Soc.) Lett. 407:207-210.

Molina, A., and Garcia-Olmedo, F. 1993. Developmental and pathogeninduced expression of three barley genes encoding lipid transfer proteins. Plant J. 4:983-691.

Morrissette, J., Kratzschmar, J., Haendler, B., Elhayek, R., MochcaMorales, J., Martin, B. M., Patel, J. R., Moss, R. L., Schleuning, W. D., Coronado, R., and Possani, L. D. 1995. Primary structure and properties of helothermine, a peptide toxin that blocks ryanodine receptors. Biophys. J. 68:2280-2288.

Nielsen, K. A., Olsen, C. E., Pontoppidan, K., and Møller, B. L. 2002. Leucine-derived cyano glucosides in barley. Plant Physiol. 129:10661075.

Rohe, M., Gierlich, A., Hermann, H., Hahn, M., Schmidt, B., Rosahl, S., and Knogge, W. 1995. The race-specific elicitor, NIP1, from the barley pathogen, Rhynchosporium secalis, determines avirulence on host plants of the Rrsl resistance genotype. EMBO (Eur. Mol. Biol. Organ.) J. 14:4168-4177.

Sambrook, J., Fritsch, E. F., and Maniatis, T. (1989). Molecular Cloning. 2nd ed. Cold Spring Harbor Laboratory, Cold Spring Harbor, NY, U.S.A.

Scala, C., Cenacchi, G., Ferrari, C., Pasquinelli, G., Preda, P., and Manara, G. C. 1992. A new acrylic resin formulation: A useful tool for histological, ultrastructural, and immunocytochemical investigations. J. Histochem. Cytochem. 40:1799-1804.

Schmelzer, E., Krueger Lebus, S., and Hahlbrock, K. 1989. Temporal and spatial patterns of gene expression around sites of attempted fungal infection in parsley leaves. Plant Cell 1:993-1002.

Selitrennikoff, C. P. 2001. Antifungal proteins. Appl. Environ. Microbiol. 67:2883-2894.

Thordal-Christensen, H., Brandt, J., Cho, B. H., Rasmussen, S. K. Gregersen, P. L., Smedegaard-Petersen, V., and Collinge, D. B. 1992. cDNA cloning and characterization of two barley peroxidase transcripts induced differentially by the powdery mildew fungus Erysiphe graminis. Physiol. Mol. Plant Pathol. 40:395-409.

Thordal-Christensen, H., Zhang, Z., Wei, Y., and Collinge, D. B. 1997. Subcellular localization of $\mathrm{H}_{2} \mathrm{O}_{2}$ in plants. $\mathrm{H}_{2} \mathrm{O}_{2}$ accumulation in papillae and hypersensitive response during the barley-powdery mildew interaction. Plant J. 11:1187-1194.

van Loon, L. C., and van Strien, E. A. 1999. The families of pathogene- sis-related proteins, their activities, and comparative analysis of PR-1 type proteins. Physiol. Mol. Plant Pathol. 55:85-97.

van Mechelen, J. R., Smits, M., Douma, A. C., Rouster, J., CameronMills, V., Heidekamp, F., and Valk, B. E. 1995. Primary structure of a lipoxygenase from barley grain as deduced from its cDNA sequence. Biochim. Biophys. Acta 1254:221-225.

van Mechelen, J. R., Schuurink, R. C., Smits, M., Graner, A., Douma, A. C., Sedee, N. J. A., Schmitt, N. F., and Valk, B. E. 1999. Molecular characterization of two lipoxygenases from barley. Plant Mol. Biol. 39:1283-1298.

Vörös, K., Feussner, I., Kühn, H., Lee, J., Graner, A., Löbler, M., Parthier, B., and Wasternack, C. 1998. Characterization of a methyljasmonateinducible lipoxygenase from barley (Hordeum vulgare cv. Salome) leaves. Eur. J. Biochem. 251:36-44

Walter, M. H., Liu, J. W., Wunn, J., and Hess, D. 1996. Bean ribonuclease-like pathogenesis-related protein genes (Ypr10) display complex patterns of developmental, dark-induced and exogenous-stimulus-dependent expression. Eur. J. Biochem. 239:281-293.

Wei, Y., Zhang, Z., Andersen, C. H., Schmelzer, E., Gregersen, P. L., Collinge, D. B., Smedegaard-Petersen, V., and Thordal-Christensen, H. 1998. An epidermis/papilla-specific oxalate oxidase-like protein in the defence response of barley attacked by the powdery mildew fungus. Plant Mol. Biol. 36:101-112.

Wevelsiep, L., Rüpping, E., and Knogge, W. 1993. Stimulation of barley plasmalemma $\mathrm{H}^{+}$-ATPase by phytotoxic peptides from the fungal pathogen Rhynchosporium secalis. Plant Physiol. 101:297-301.

Williamson, M. S., Forde, J., Buxton, B., and Kreis, M. 1987. Nucleotide sequence of barley chymotrypsin inhibitor-2 (CI-2) and its expression in normal and high-lysine barley. Eur. J. Biochem. 165:99-106.

Wojtaszek, P. 1997. Oxidative burst: An early plant response to pathogen infection. Biochem. J. 322:681-692.

Woo, E. J., Dunwell, J. M., Goodenough, P. W., Marvier, A. C., and Pickersgill, R. W. 2000. Germin is a manganese containing homohexamer with oxalate oxidase and superoxide dismutase activities. Nature Struct. Biol. 7:1036-1040.

Yamahara, T., Shiono, T., Suzuki, T., Tanaka, K., Takio, S., Sato, K., Yamazaki, S., and Satoh, T. 1999. Isolation of a germin-like protein with manganese superoxide dismutase activity from cells of a moss, Barbula unguiculata. J. Biol. Chem. 274:33274-33278.

Zarembinski, T. I., Hung, L. W., Mueller-Dieckmann, H. J., Kim, K. K., Yokota, H., Kim, R., and Kim, S. H. 1998. Structure-based assignment of the biochemical function of a hypothetical protein: A test case of structural genomics. Proc. Natl. Acad. Sci. U.S.A. 95:15189-15193.

Zhou, F., Zhang, Z., Gregersen, P. L., Mikkelsen, J. D., de Neergaard, E., Collinge, D. B., and Thordal-Christensen, H. 1998. Molecular characterization of the oxalate oxidase involved in the response of barley to the powdery mildew fungus. Plant Physiol. 117:33-41.

Zhou, F. S., Andersen, C. H., Burhenne, K., Fischer, P. H., Collinge, D. B., and Thordal-Christensen, H. 2000. Proton extrusion is an essential signaling component in the HR of epidermal single cells in the barleypowdery mildew interaction. Plant J. 23:245-254. 